\title{
Isoflavone diglycosides from Glycosmis pentaphylla
}

Junsong Wang, Xianwen Yang, Yingtong Di, Yuehu Wang, Yuemao Shen, and

Xiaojiang Hao*

State Key Laboratory of Phytochemistry and Plant Resources in West China, Kunming

Institute of Botany, Chinese Academy of Sciences, Kunming 650204, PR China

* To whom correspondence should be addressed, Tel: +86-871-522-3263

Fax:+86-871-515-0227 E-mail: haoxj@mail.kib.ac.cn

\section{Surpporting Information}

Figure S1. ${ }^{1} \mathrm{H}$ NMR spectrum of 1 (500 MHz, CD3OD)

Figure S2. ${ }^{13} \mathrm{C}$ and DEPT NMR spectra of $\mathbf{1}\left(125 \mathrm{MHz}, \mathrm{CD}_{3} \mathrm{OD}\right)$

Figure S3. HSQC spectrum of $1\left(\mathrm{CD}_{3} \mathrm{OD}\right)$

Figure S4. HMBC spectrum of $1\left(\mathrm{CD}_{3} \mathrm{OD}\right)$

Figure S5. ${ }^{1} \mathrm{H}$ NMR spectrum of 2 (500 MHz, CD3OD)

Figure S6. ${ }^{13} \mathrm{C}$ and DEPT NMR spectra of 2 (125 MHz, CD $\left.3 \mathrm{OD}\right)$

Figure S7. HSQC spectrum (Part A) of 2 (CD3OD)

Figure S8. HSQC spectrum (Part B) of $\mathbf{2}\left(\mathrm{CD}_{3} \mathrm{OD}\right)$

Figure S9. HMBC spectrum of $2\left(\mathrm{CD}_{3} \mathrm{OD}\right)$

Figure S10. ${ }^{1} \mathrm{H}$ NMR spectrum of $3\left(500 \mathrm{MHz}, \mathrm{CD}_{3} \mathrm{OD}\right)$ 
Figure S11. ${ }^{13} \mathrm{C}$ and DEPT NMR spectra of $\mathbf{3}$ (125 MHz, CD $3 \mathrm{OD}$ )

Figure S12. ${ }^{1} \mathrm{H}$ NMR spectrum of $\mathbf{4}\left(500 \mathrm{MHz}, \mathrm{CD}_{3} \mathrm{OD}\right)$

Figure S13. ${ }^{13} \mathrm{C}$ and DEPT NMR spectra of $\mathbf{4}\left(125 \mathrm{MHz}, \mathrm{CD}_{3} \mathrm{OD}\right)$

Figure S14. ${ }^{1} \mathrm{H}$ NMR spectrum of $5\left(500 \mathrm{MHz}, \mathrm{CD}_{3} \mathrm{OD}\right)$

Figure S15. ${ }^{13} \mathrm{C}$ and DEPT NMR spectra of 5 (125 MHz, CD 30 OD)

Figure S16. ${ }^{1} \mathrm{H}$ NMR spectrum of $6\left(500 \mathrm{MHz}, \mathrm{C}_{5} \mathrm{D}_{5} \mathrm{~N}\right)$

Figure S17. ${ }^{13} \mathrm{C}$ and DEPT NMR spectra of $6\left(125 \mathrm{MHz}, \mathrm{C}_{5} \mathrm{D}_{5} \mathrm{~N}\right)$ 


\section{Figure S1. ${ }^{1} \mathrm{H}$ NMR spectrum of $1\left(500 \mathrm{MHz}, \mathrm{CD}_{3} \mathrm{OD}\right)$}

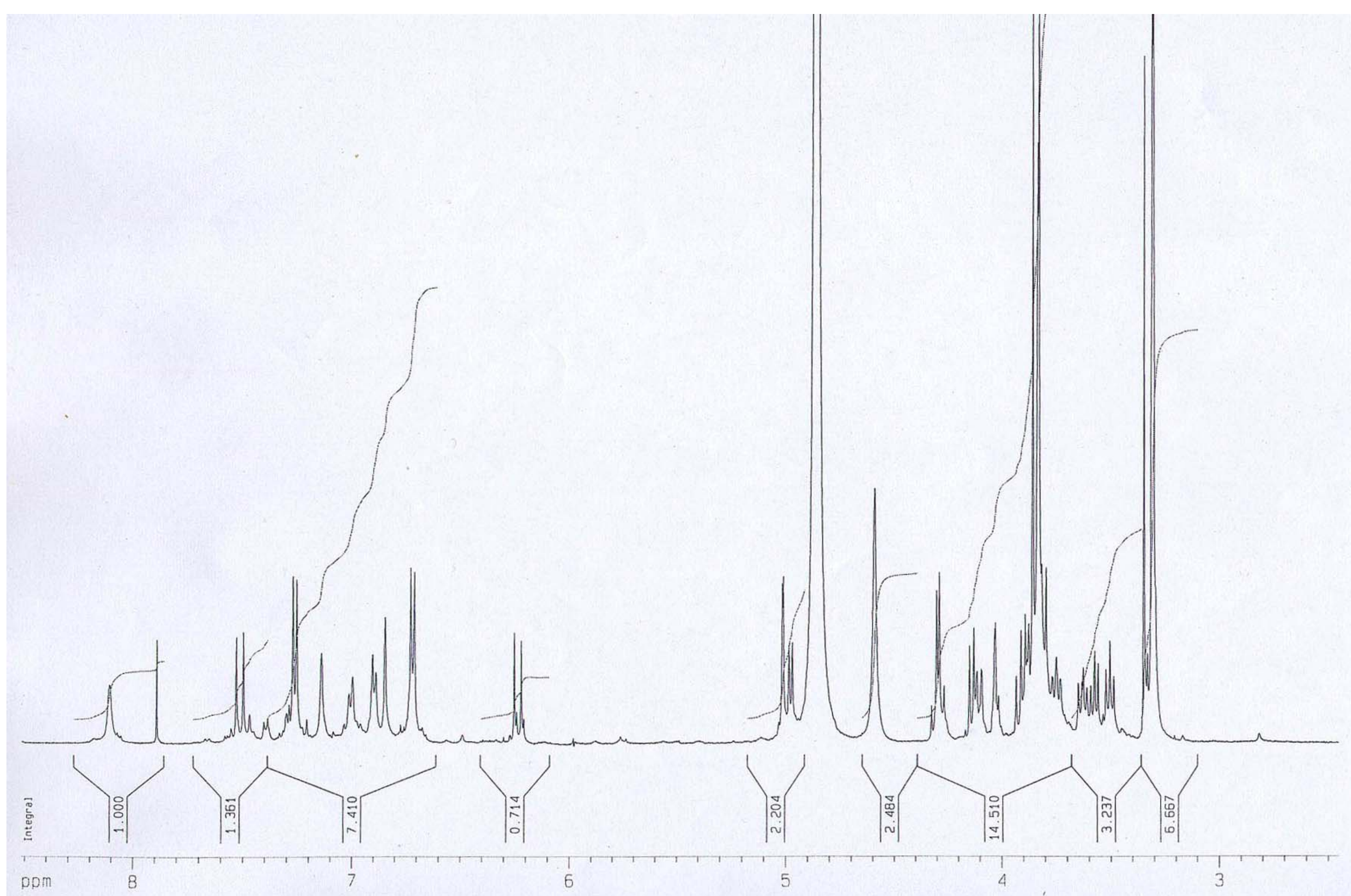


Figure S2. ${ }^{13} \mathrm{C}$ and DEPT NMR spectra of 1 (125 MHz, $\left.\mathrm{CD}_{3} \mathrm{OD}\right)$

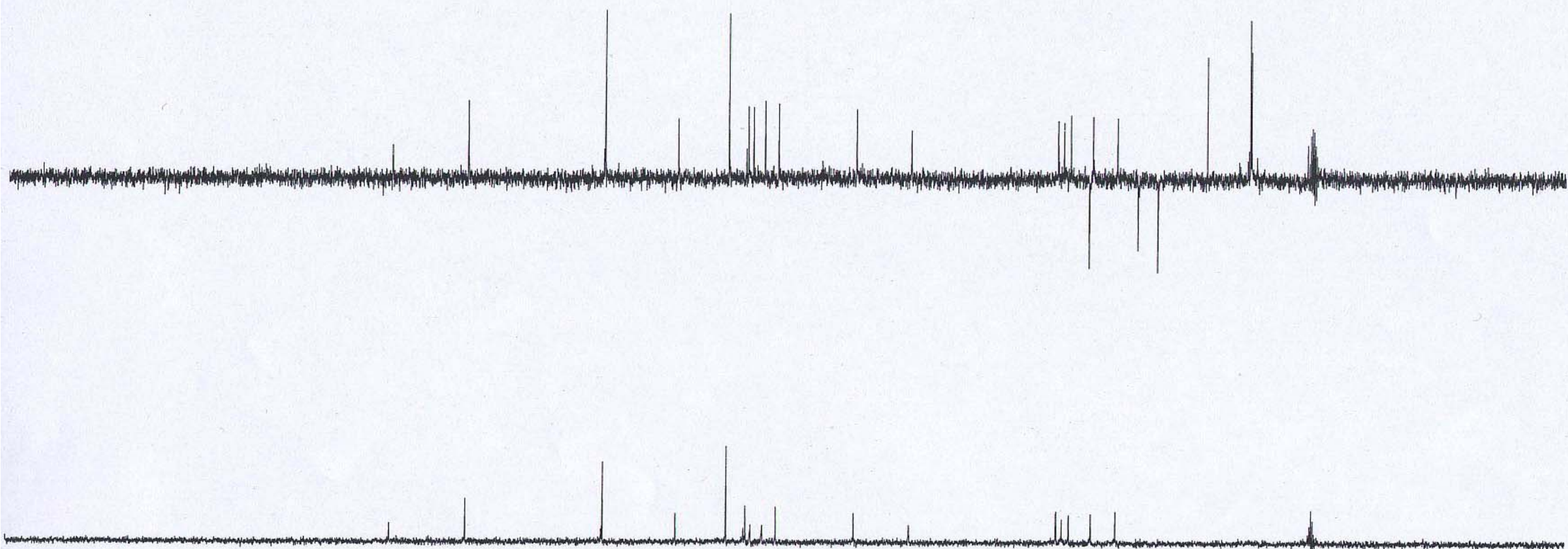

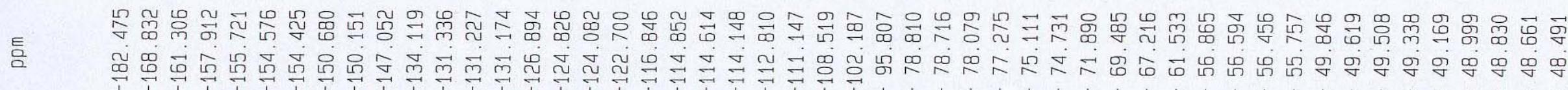

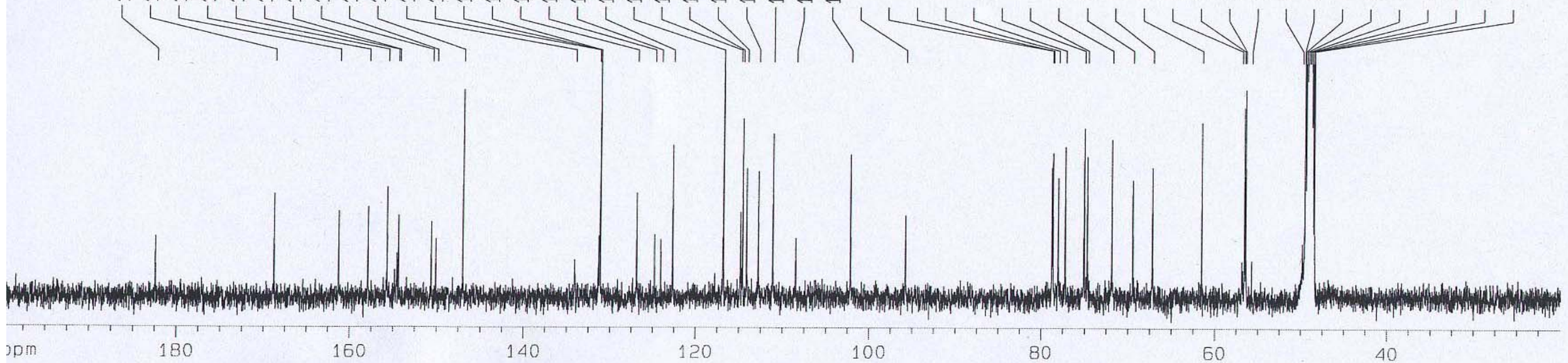


Figure S3. HSQC spectrum of $\mathbf{1}\left(\mathrm{CD}_{3} \mathrm{OD}\right)$

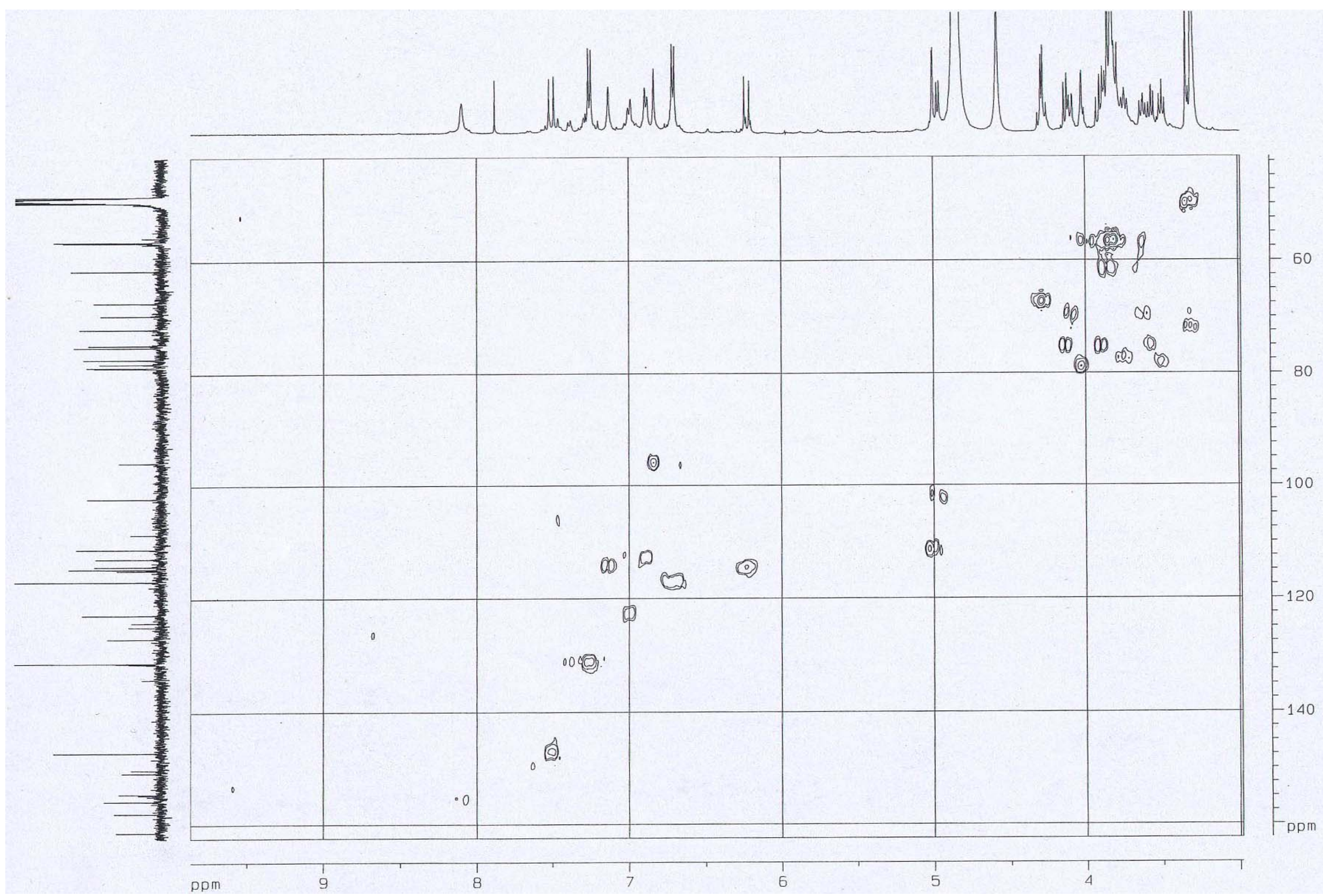


Figure S4. HMBC spectrum of $1\left(\mathrm{CD}_{3} \mathrm{OD}\right)$

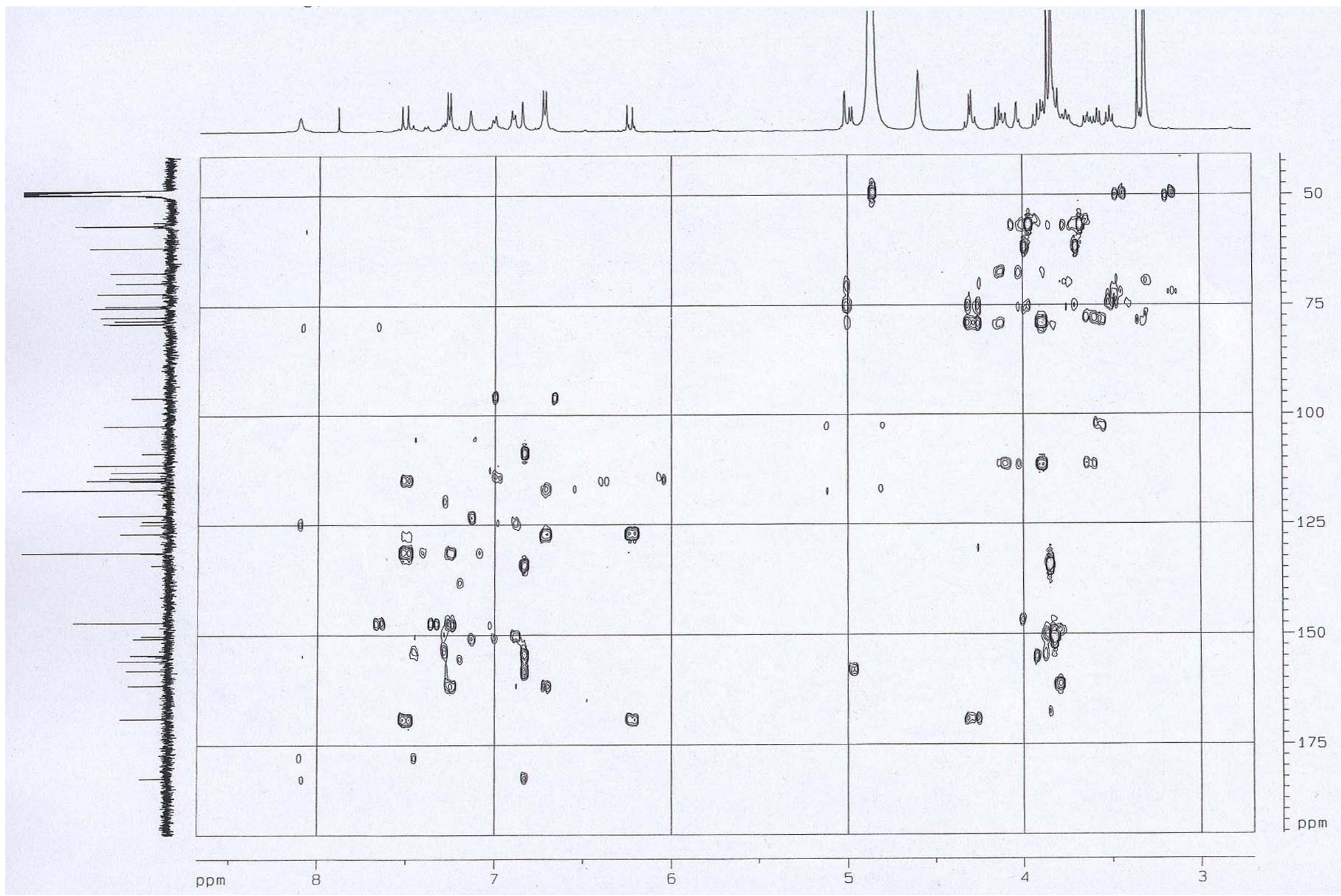


Figure S5. ${ }^{1} \mathrm{H}$ NMR spectrum of $2\left(500 \mathrm{MHz}, \mathrm{CD}_{3} \mathrm{OD}\right)$

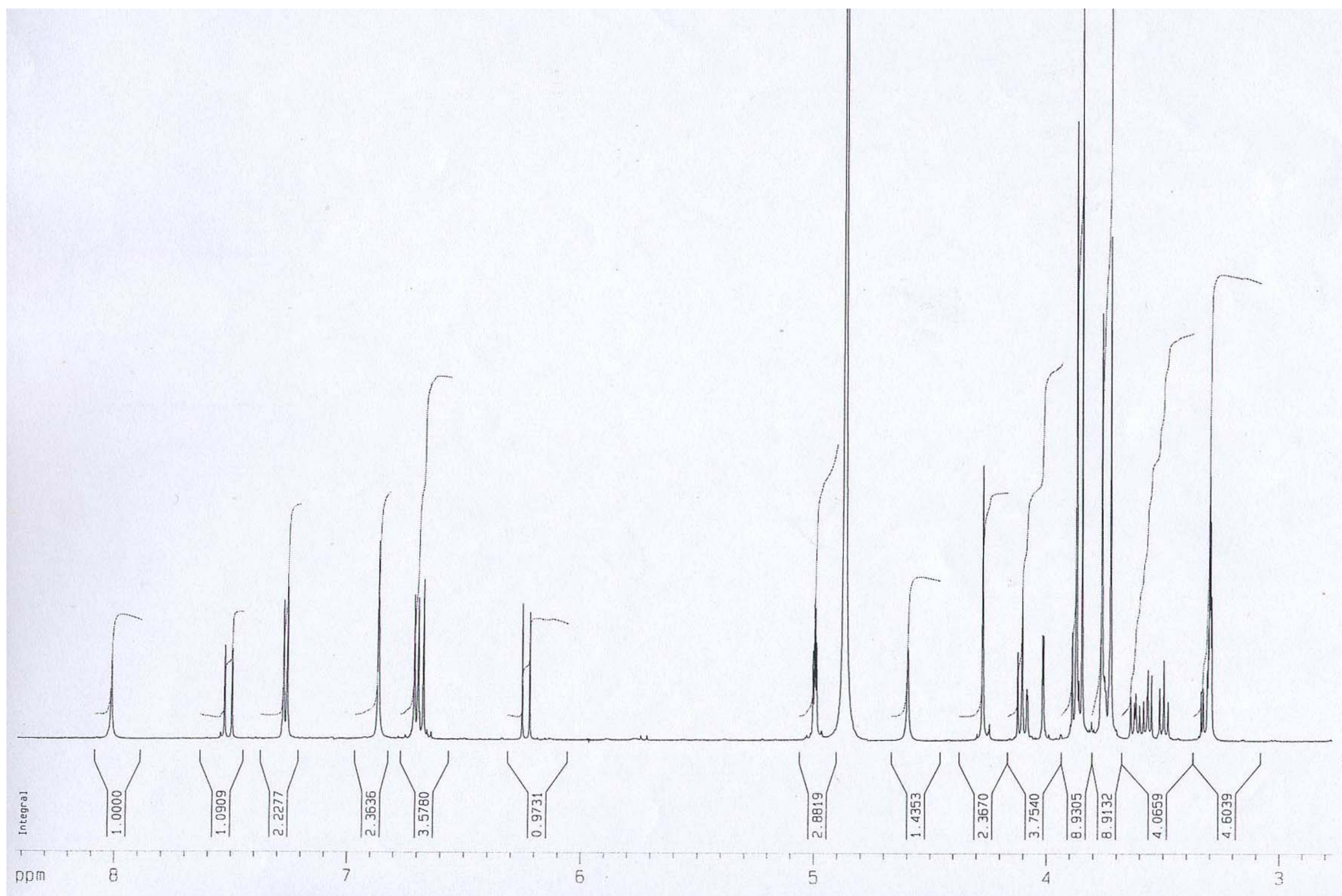


Figure S6. ${ }^{13} \mathrm{C}$ and DEPT NMR spectra of $2\left(125 \mathrm{MHz}, \mathrm{CD}_{3} \mathrm{OD}\right)$
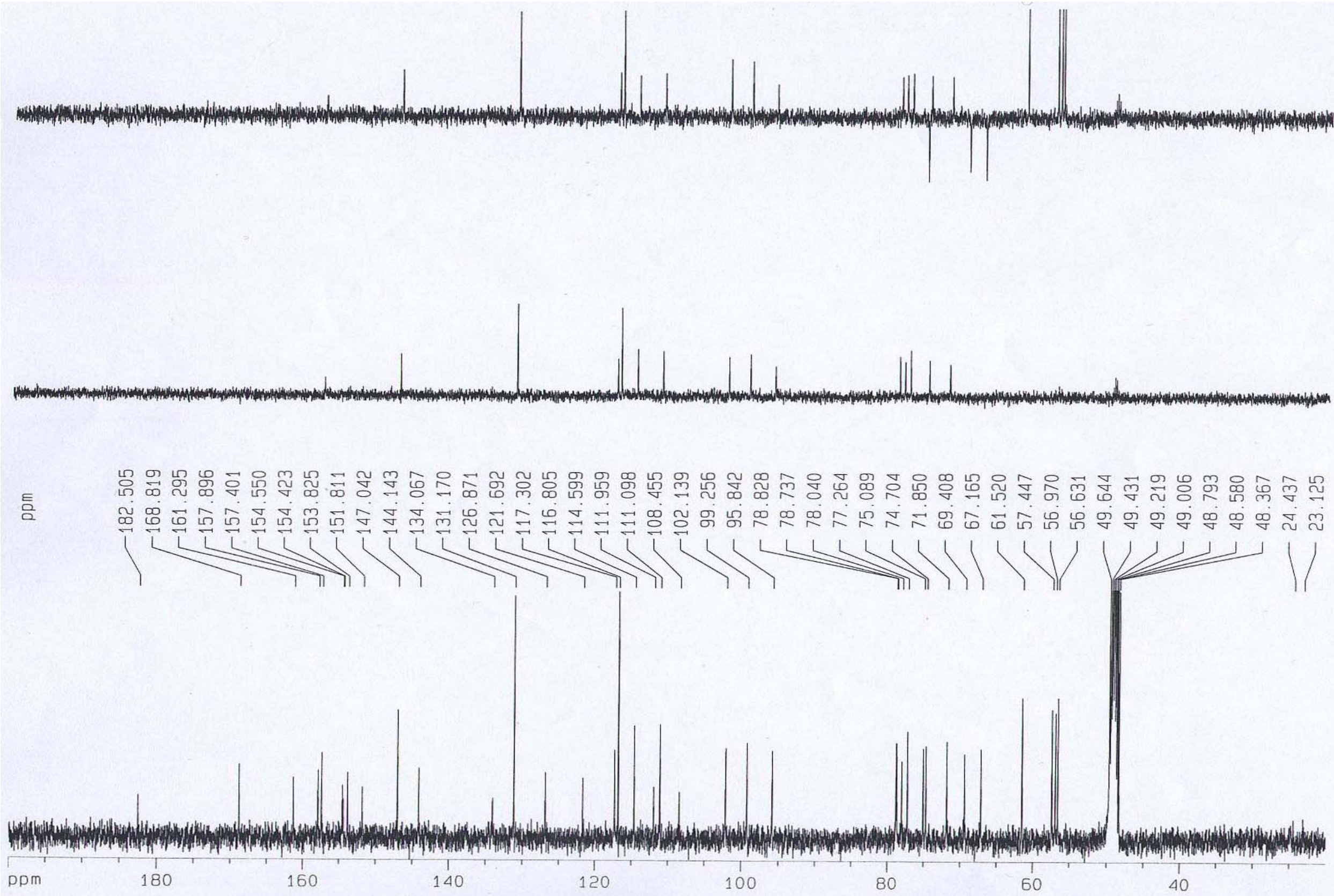
Figure S7. HSQC spectrum (Part A) of $\mathbf{2}\left(\mathrm{CD}_{3} \mathrm{OD}\right)$

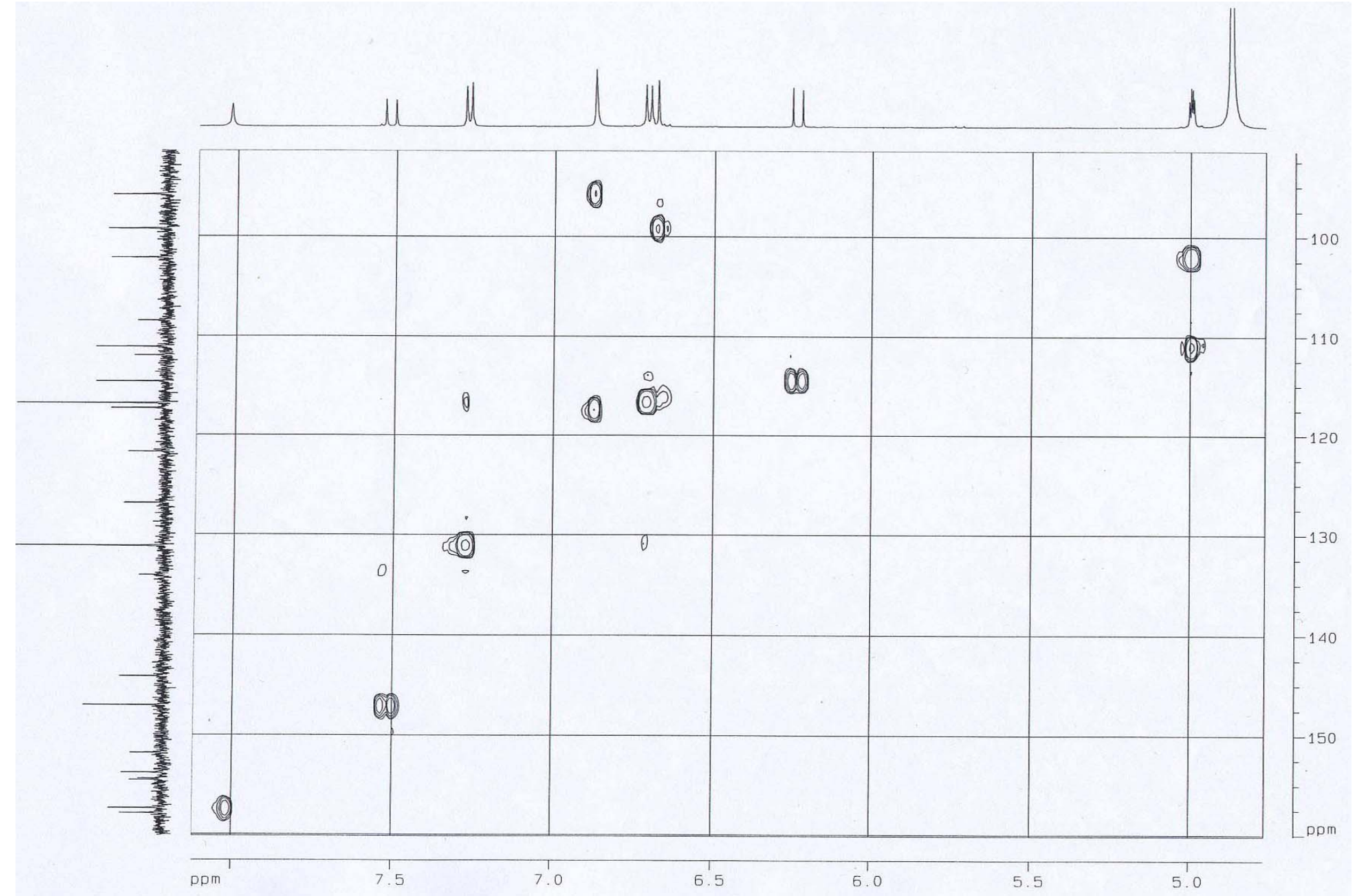


Figure S8. HSQC spectrum (Part B) of $\mathbf{2}\left(\mathrm{CD}_{3} \mathrm{OD}\right)$

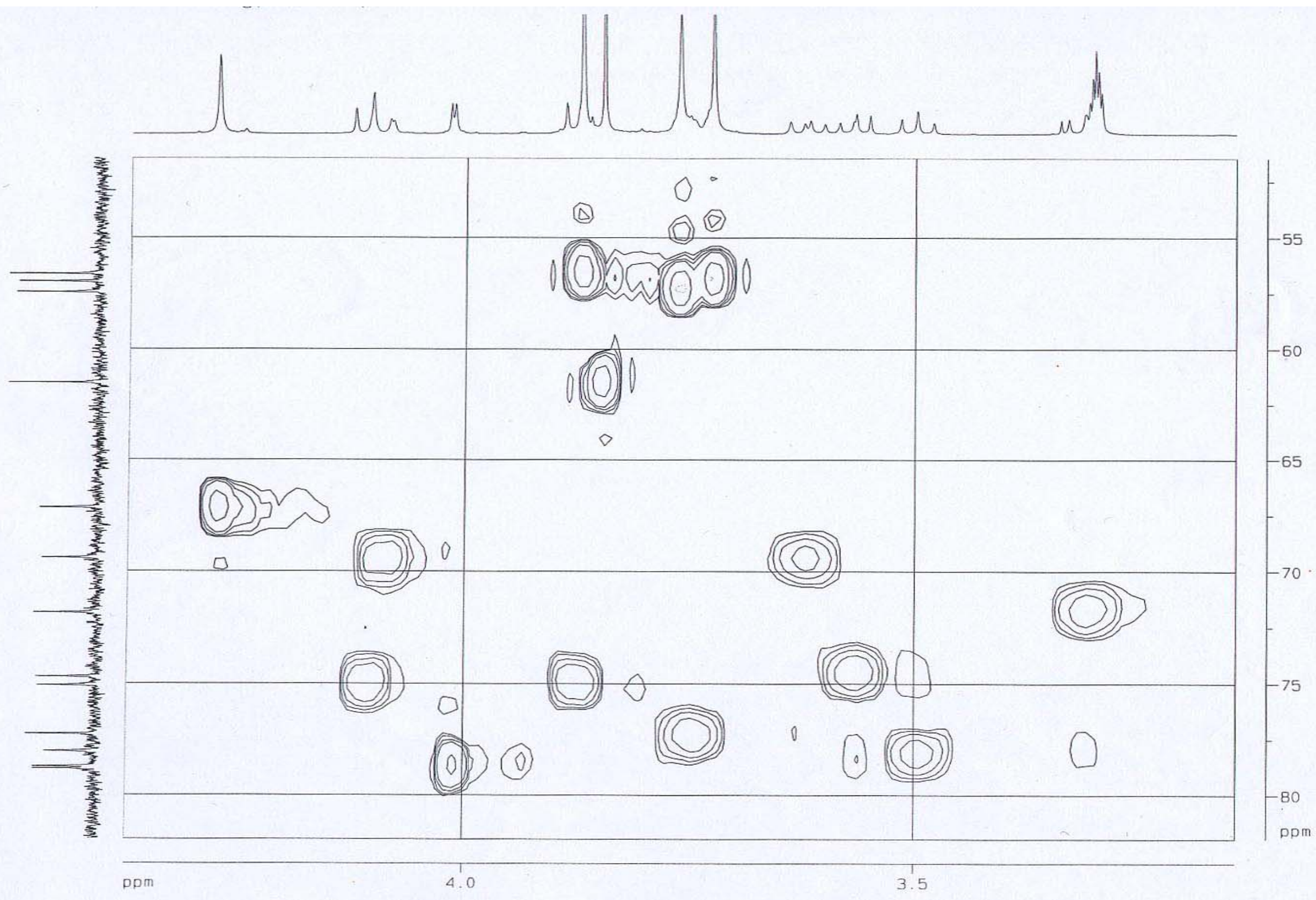


Figure S9. $\mathrm{HMBC}$ spectrum of $\mathbf{2}\left(\mathrm{CD}_{3} \mathrm{OD}\right)$

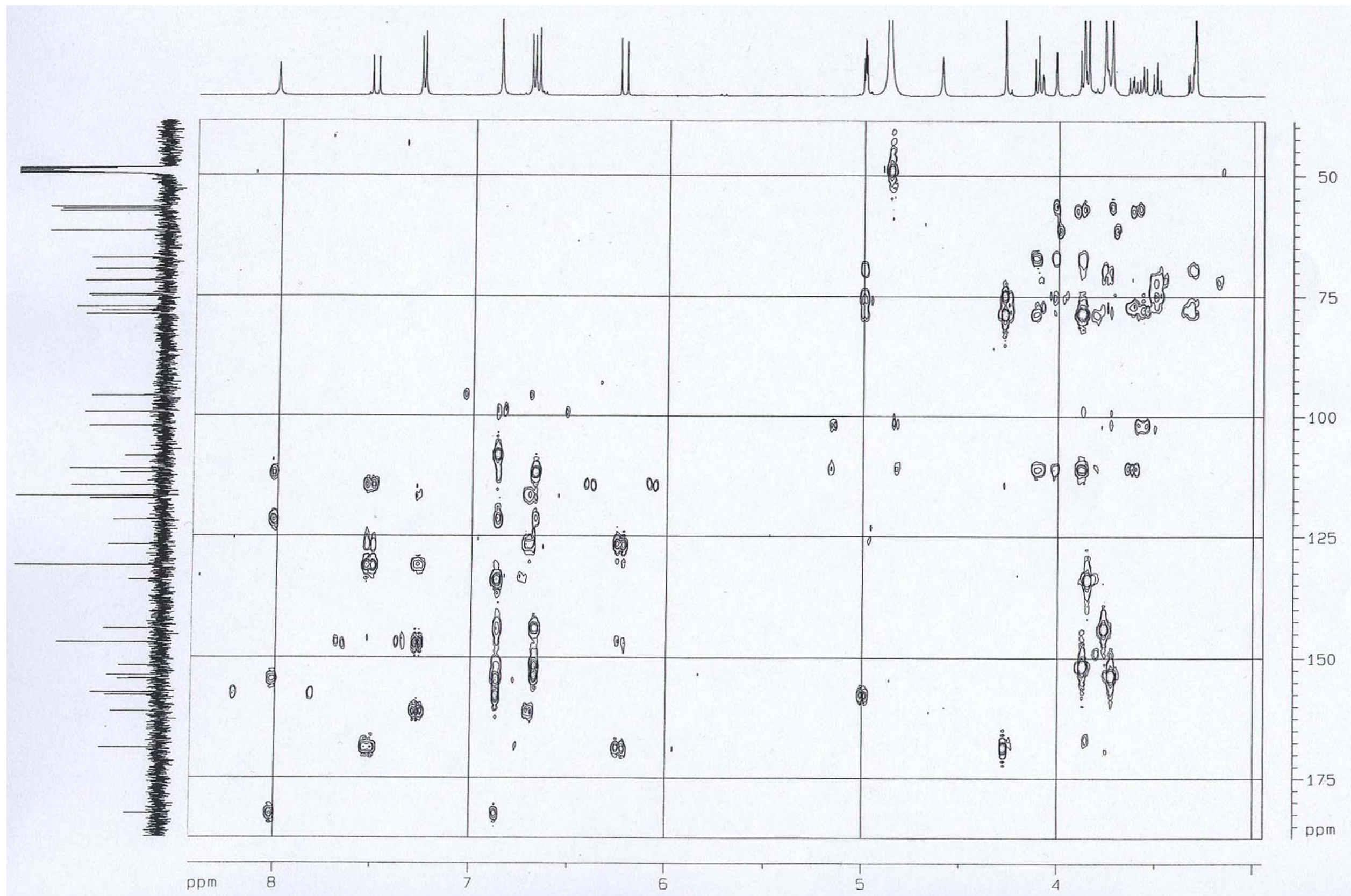


Figure S10. ${ }^{1} \mathrm{H}$ NMR spectrum of 3 (500 MHz, $\left.\mathrm{CD}_{3} \mathrm{OD}\right)$

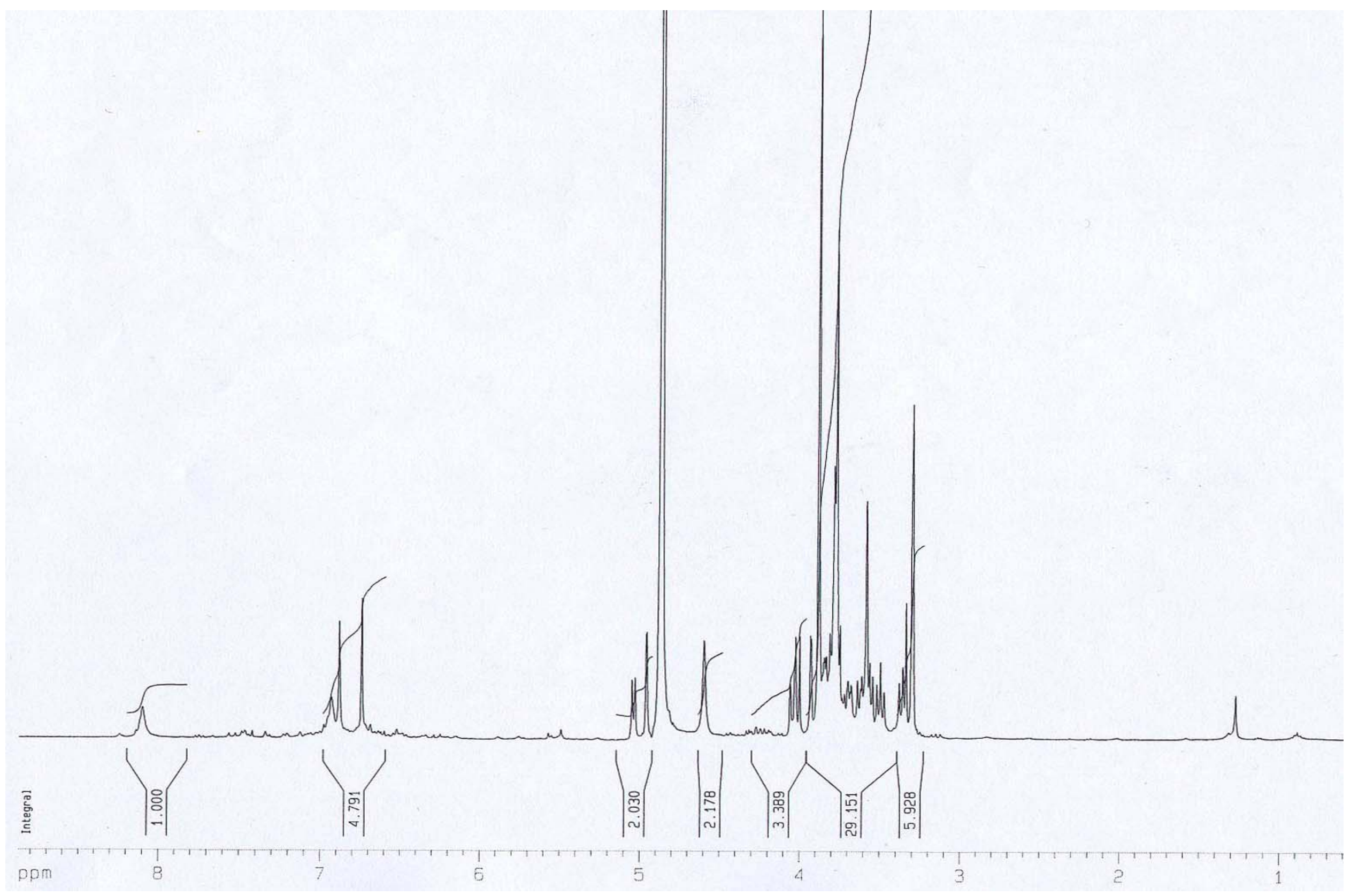


Figure S11. ${ }^{13} \mathrm{C}$ and DEPT NMR spectra of 3 (125 MHz, CD $\left.{ }_{3} \mathrm{OD}\right)$
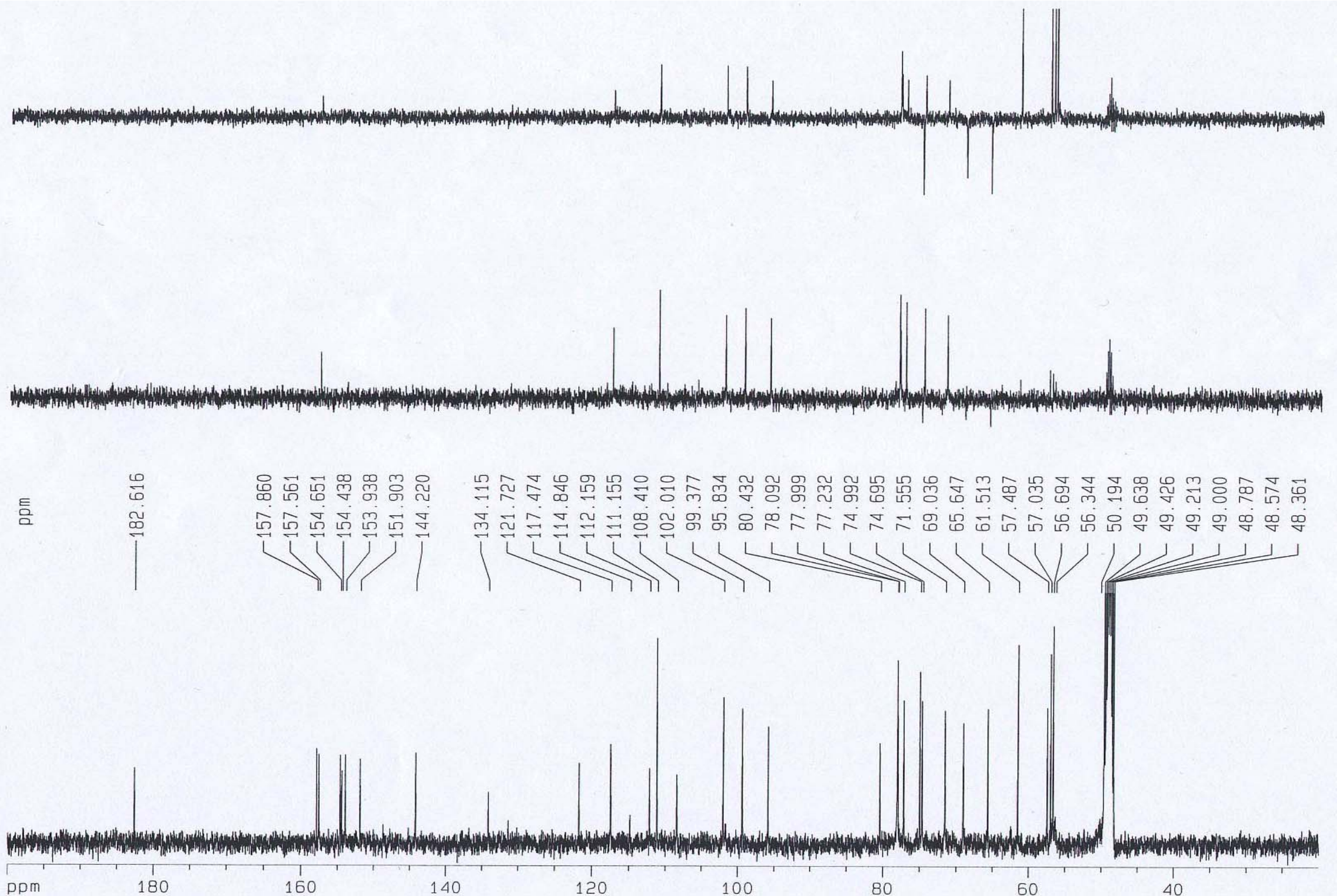
Figure S12. ${ }^{1} \mathrm{H}$ NMR spectrum of 4 (500 MHz, $\left.\mathrm{CD}_{3} \mathrm{OD}\right)$

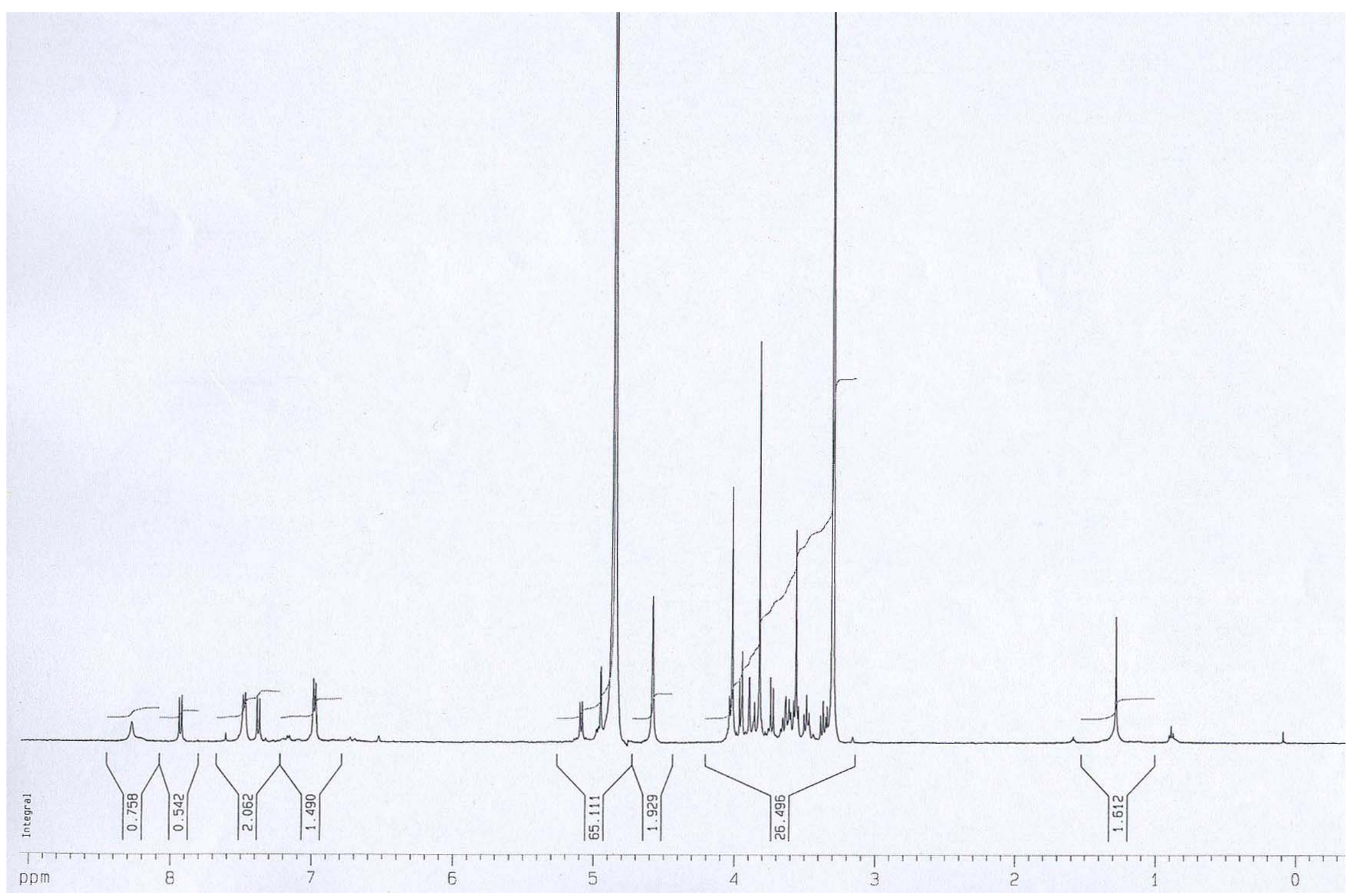


Figure S13. ${ }^{13} \mathrm{C}$ and DEPT NMR spectra of 4 (125 MHz, $\left.\mathrm{CD}_{3} \mathrm{OD}\right)$
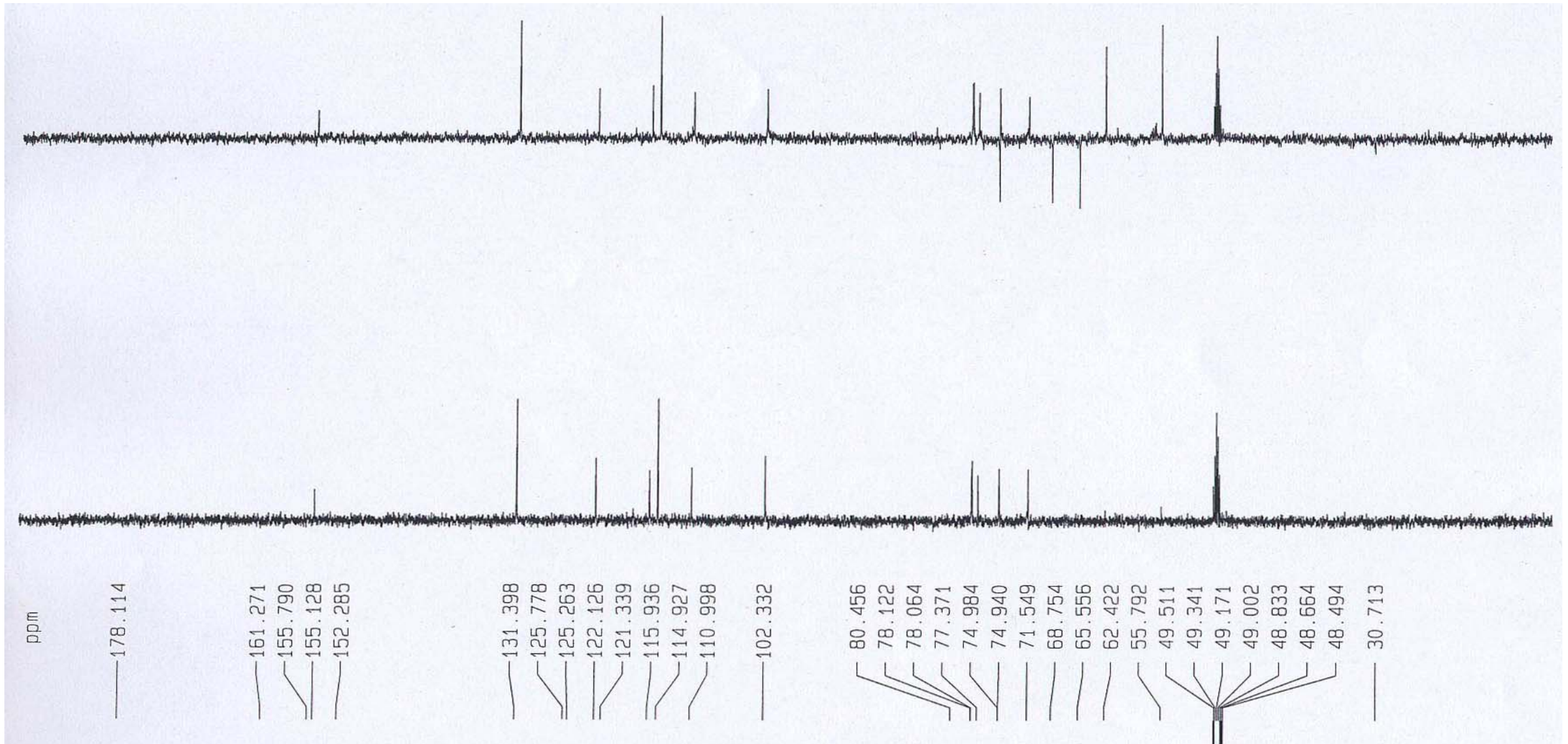
Figure S14. ${ }^{1} \mathrm{H}$ NMR spectrum of 5 (500 MHz, $\left.\mathrm{CD}_{3} \mathrm{OD}\right)$

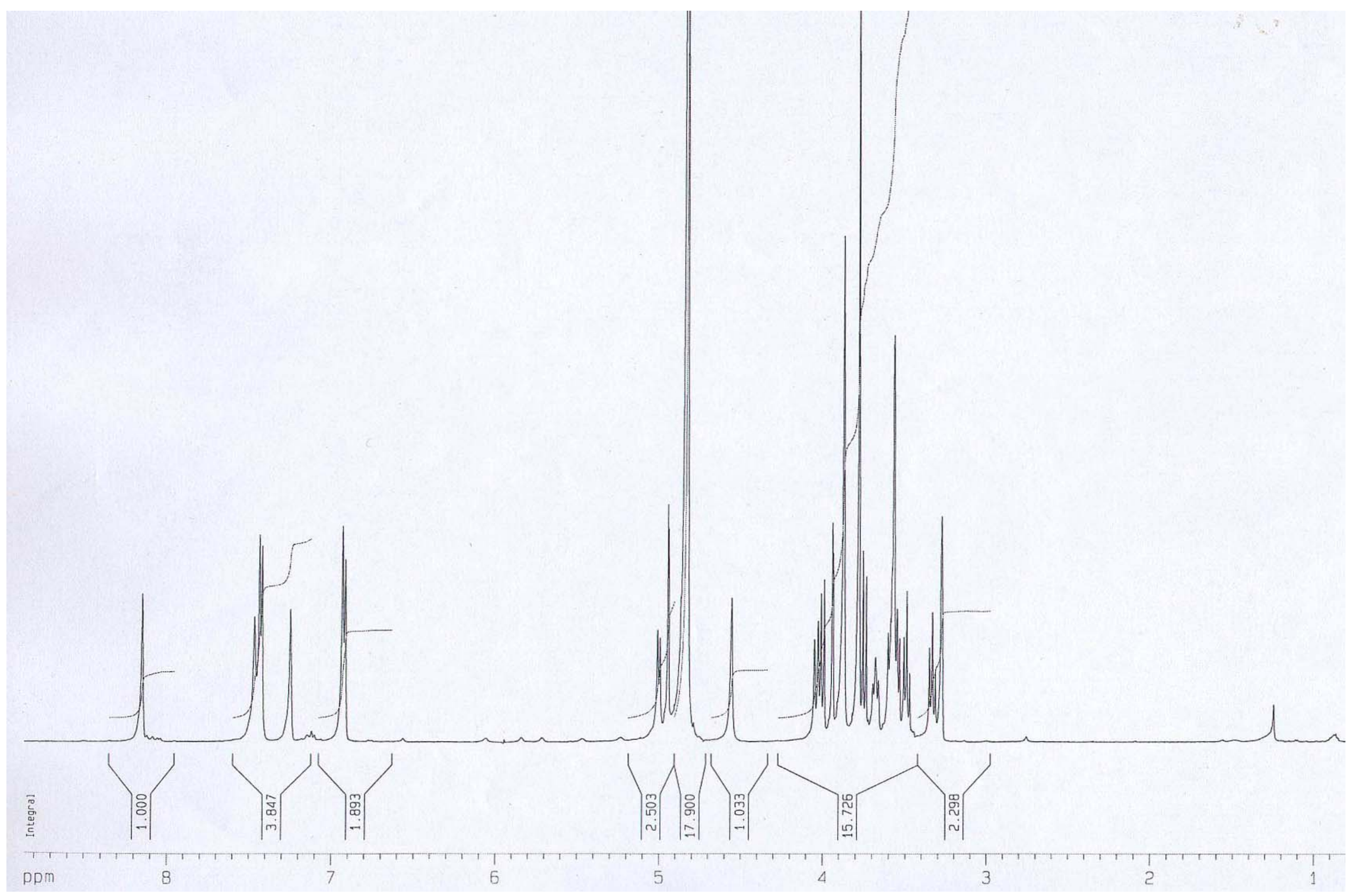


Figure S15. ${ }^{13} \mathrm{C}$ and DEPT NMR spectra of 5 (125 MHz, $\left.\mathrm{CD}_{3} \mathrm{OD}\right)$
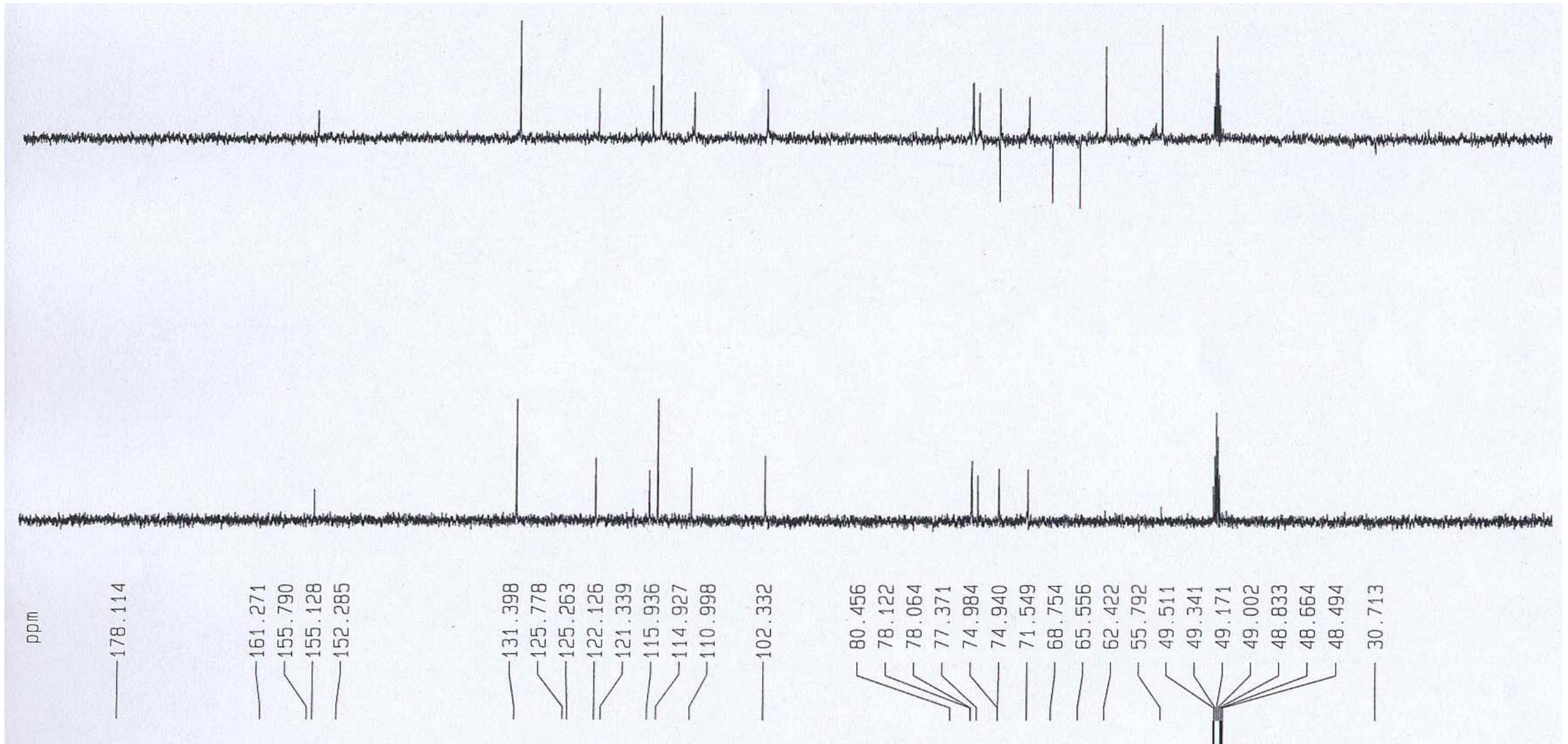
Figure S16. ${ }^{1} \mathrm{H}$ NMR spectrum of $6\left(500 \mathrm{MHz}, \mathrm{C}_{5} \mathrm{D}_{5} \mathrm{~N}\right)$

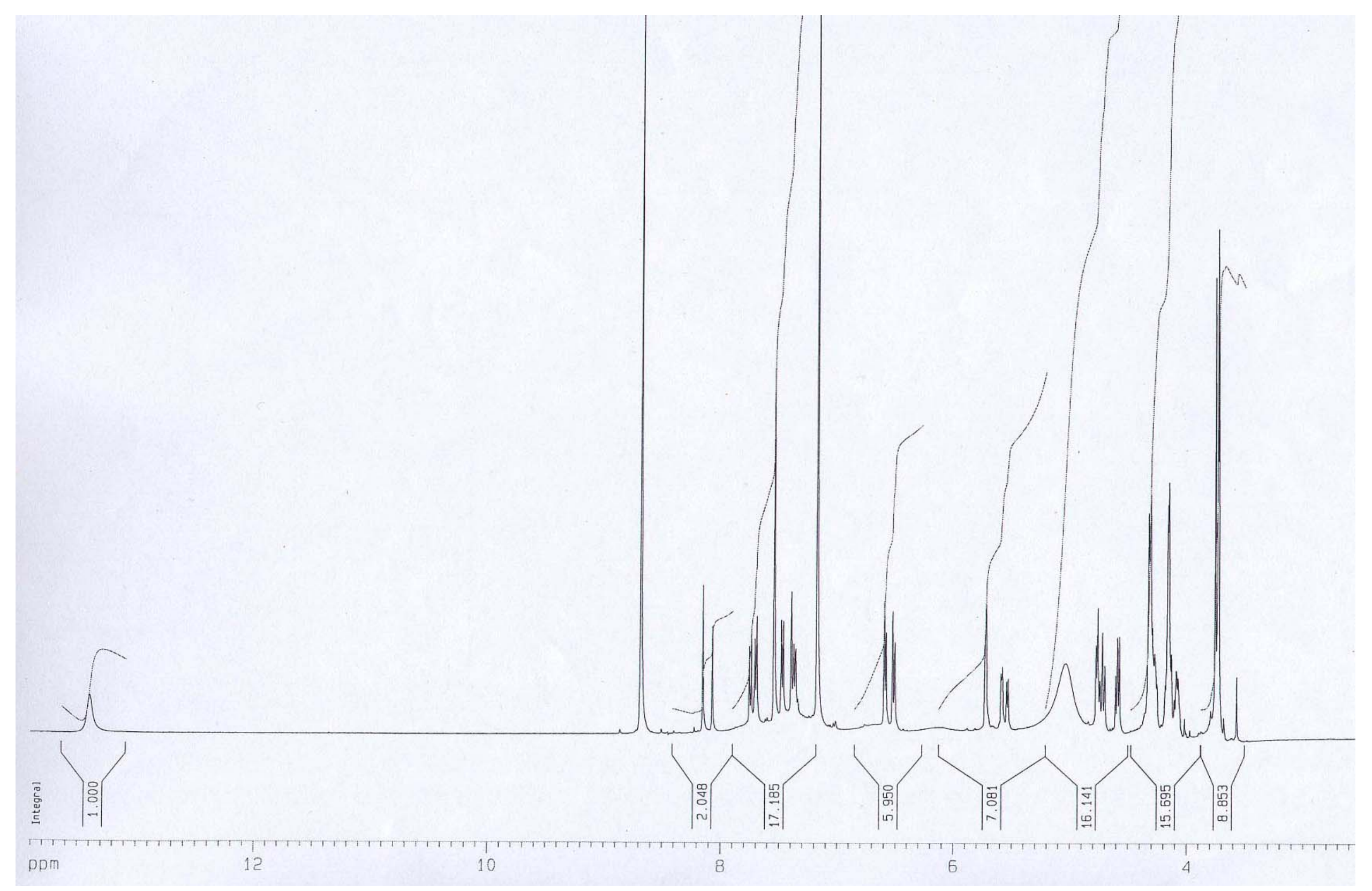


Figure S17. ${ }^{13} \mathrm{C}$ and DEPT NMR spectra of $6\left(125 \mathrm{MHz}, \mathrm{C}_{5} \mathrm{D}_{5} \mathrm{~N}\right)$

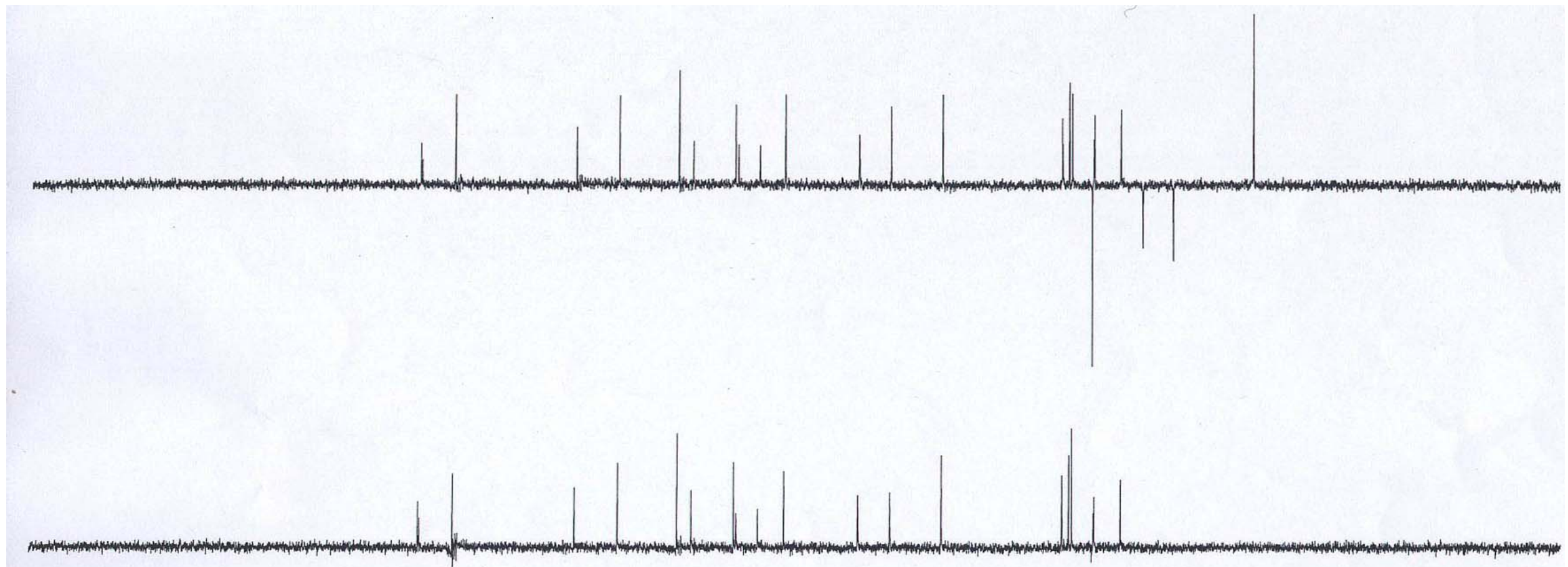

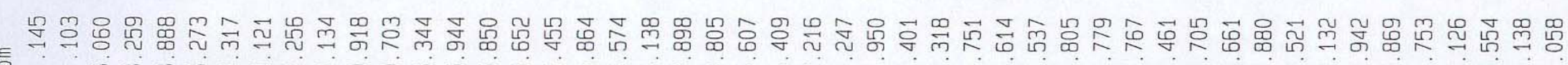

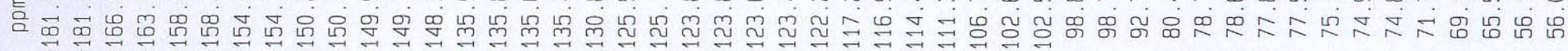

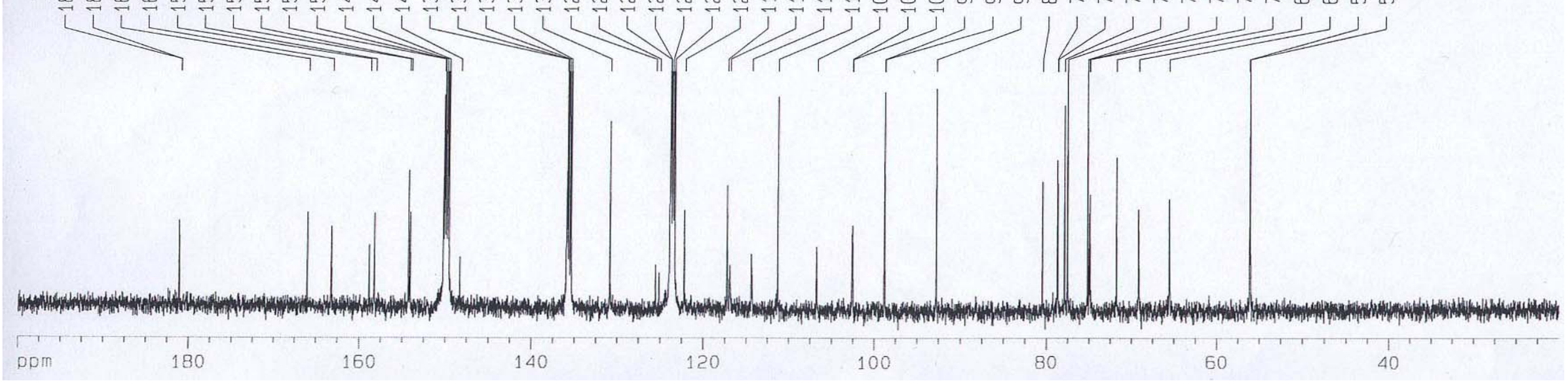

